\title{
Study of treatment response to anemia in females admitted in tertiary care hospital
}

\author{
Neelima S Deshpande ${ }^{1}$, Khan Nazneen Jameel Khan ${ }^{2 *}$
}

${ }^{1}$ Professor \& HOD, ${ }^{2}$ Resident, Department of Medicine, Vilasrao Deshmukh Government Institute of Medical Sciences, Latur, Maharashtra. Email: dr.neelima08@gmail.com, milestone10015028@gmail.com

Abstract Background: Anaemia is a major public health problem worldwide, particularly in females. The attitude and knowledge of the women about anaemia and supplements is probably the missing link and is an important factor as a barrier for motivation for anaemia treatments. Aim: To evaluate treatment response to anaemia of various types in females admitted in our tertiary care hospital. Material and Methods: A total of 60 females were selected in each group and there were three groups (12-30years)(31-50years) (more than 50years).Type of anaemia was established after laboratory investigations. The females after diagnosis with anaemia are treated with different modes of treatment including oral and injectable form of supplements. Treatment response was evaluated. Results: Iron deficiency anaemia females shows the very good response to iron folic acid supplement making an important steps of preventing iron deficiency anaemia in females if there is timely distribution of iron folic acid tablets among the females. Similarly, the females with the megaloblastic anaemia were treated with the syrup vitcofol had shown the very good response to treatment. In patients with anaemia due to chronic diseases, the injectable erythropoietin was used along with the iron sucrose, this had drastically improve the red cell indices thereby reducing the need of transfusion. Conclusion: The present need of the health care system is to develop the awareness among the females about available anaemia treatments. The oral supplements have good response to treatment. Food fortification with important micronutrients can have the better impact on the nutritional status.

Keywords: Anaemia, females, iron, folic acid, erythropoetin, response.

\section{*Address for Correspondence:}

Dr Khan Nazneen Jameel Khan, Resident, Department of Medicine, Vilasrao Deshmukh Government Institute of Medical Sciences, Latur, Maharashtra, INDIA.

Email: milestone10015028@gmail.com

Received Date: 23/05/2020 Revised Date: 39/07/2020 Accepted Date: 05/08/2020

DOI: https://doi.org/10.26611/10211535

This work is licensed under a Creative Commons Attribution-NonCommercial 4.0 International License. (cc) EY-NC

\begin{tabular}{|l|l|}
\hline \multicolumn{2}{|c|}{ Access this article online } \\
\hline Quick Response Code: & Website: \\
\hline & www.medpulse.in \\
\hline
\end{tabular}

\section{INTRODUCTION}

Anaemia is a major public health problem worldwide, particularly in females. The importance of anaemia as a major public health problem throughout the world and its widely recognized. In India, it is classified as a major public health problem as it is estimated that $52 \%$ of nonpregnant women of reproductive age are anemic. ${ }^{1}$ Interventions to reduce the burden of anaemia and iron deficiency anaemia should address the causatives. Costeffective anaemia prevention and control strategies are well-documented and have the power for their intended objectives in different countries. Despite increased national and international awareness and recent governmental intervention programs, the prevalence of anaemia among Indian women has remained higher than $45 \%$ since 1990, and anaemia trends remain strongly correlated with iron-deficiency. ${ }^{1}$ The present study was conducted to evaluate treatment response to anaemia of various types in females admitted in our tertiary care hospital.

\section{MATERIAL AND METHODS}

Type of study Prospective observational study

Sampling method Three groups were formed by simple random sampling. Each individual was chosen randomly and entirely by chance, such that each individual has the same probability of being chosen at any stage during the sampling process, and each subset 
of $k$ individuals has the same probability of being chosen for the sample as any other subset of $k$ individual. A total of 60 females were selected in each group and there were three groups (12-30years)(31-50years) (more than 50years). Sample size was determined using the expected proportion of event/outcome in each group values of which were estimated from literature and using the formula, $n=$ $\left(Z_{\alpha}+Z_{\beta}\right)^{2}[p(1-p)+q(1-q)] /(p-q)^{2}$ where $Z_{\alpha}=z$ variate of alpha error i.e. a constant with value $1.96 ; Z_{\beta}=a$ constant with value $0.84 ; \mathrm{p}, \mathrm{q}=$ proportions of the variable, values taken from previous study. ${ }^{3}$

\section{Inclusion criteria}

- All women (more than 12 years) visiting tertiary health care centre with $\mathrm{Hb}$ level less than $12 \mathrm{gm} / \mathrm{dl}$.

\section{Exclusion criteria}

- Pregnant females.

- Females less than 12 years.

The females after their history taking, clinical examination and laboratory diagnosis were treated. In case of iron deficiency anaemia, the females were given the supplement of iron tablet containing elemental iron $100 \mathrm{mg}$ twice a day for 3 months. The patients with megaloblastic anaemia were treated with syrup containing cyanocobalamin $5 \mathrm{mcg}$, ferrous fumarate $100 \mathrm{mg}$ and folic acid $0.5 \mathrm{mg}$ per $5 \mathrm{ml}$ of the syrup taking $5 \mathrm{ml}$ BID for three months. The patients with hemolytic anaemia were treated with blood transfusions. The patient with anaemia due to chronic disease in females with chronic kidney disease were treated with erythropoietin 50-100 units/kg IV 3 times weeks for 3 months and were follow up to see the response to the treatment. Haemoglobin estimation was done by Sahli's method. CBC was done by Sysmex automated hematology analyzer. Peripheral smear examination was done after blood films stained with Romanowsky stains such as Wright's stain, Giemsa stain or Diff-Quik stains for the detection of white blood cell, red blood cell and platelet abnormalities. On the basis of peripheral smear examination, the anaemia were classified as:Microcytic hypochromic anaemia, macrocytic normochromic anaemia and normocytic normochromic anaemia. Cell lineage study was done by bone marrow aspiration. Serum ferritin level was measured with enzyme linked immunosorbent assay. The normal range of Sr.ferritin is 12-300nanogm $/ \mathrm{ml}$.Serum vitamin B12 level was measured by Roche Modular P chemistry analyzer. The normal range of Sr. vitamin B12-200-900 nanogm $/ \mathrm{ml}$. Serum LDH (Lactate dehydrogenase) levels were also measured. LDH level is $140 \mathrm{U} / \mathrm{L}-280 \mathrm{U} / \mathrm{L}$. Hemoglobin electrophoresis was done by electrophoresis machine. The expected normal range for $\mathrm{HbA}_{2}$ is between $1.7 \%$ and $3.2 \%$ in normal subjects, while in $\beta$-thalassaemia carriers when it is between $4.0 \%$ and $7 \%$. $\mathrm{HbA}_{2}$ values are considered borderline when between $3.2 \%$ and $3.8 \%$. Samples with these levels need further investigation for possible normal $\mathrm{HbA}_{2}$ thalassaemia. The normal range for $\mathrm{HbF}$ is usually less than $1.5 \%$ of total hemoglobin.

\section{RESULTS}

In present study, the females are studied in three age groups ,the females in the three age groups are divided into the grade of severity of anaemia as mild, moderate and severe on the basis of hemoglobin concentration as mild -less than $10 \mathrm{gm} / \mathrm{dl}$ ,moderate $7-10 \mathrm{gm} / \mathrm{dl}$ and severe -less than $7 \mathrm{gm} / \mathrm{dl}$.

Table 1: Incidence of anaemia according to grades of severity

\begin{tabular}{|c|c|c|c|c|c|c|}
\hline \multirow[t]{2}{*}{ Severity of anaemia } & \multicolumn{2}{|c|}{$\begin{array}{l}\text { Age group } \\
12-30 \text { years }\end{array}$} & \multicolumn{2}{|c|}{$\begin{array}{l}\text { Age group } \\
31-50 \text { years }\end{array}$} & \multicolumn{2}{|c|}{$\begin{array}{l}\text { Age group } \\
>50 \text { years }\end{array}$} \\
\hline & $\mathrm{N}$ & $\%$ & $\mathrm{~N}$ & $\%$ & $\mathrm{~N}$ & $\%$ \\
\hline Mild anaemia & 5 & 8.4 & 5 & 8.3 & 9 & 15 \\
\hline Moderate anaemia & 25 & 41.6 & 29 & 48.3 & 30 & 50 \\
\hline Severe anaemia & 30 & 50 & 26 & 43.4 & 21 & 35 \\
\hline
\end{tabular}

Table 1. shows the incidence of moderate anaemia is maximum among the three age groups. The incidence of moderate grade of anaemia is maximum in all three age groups.

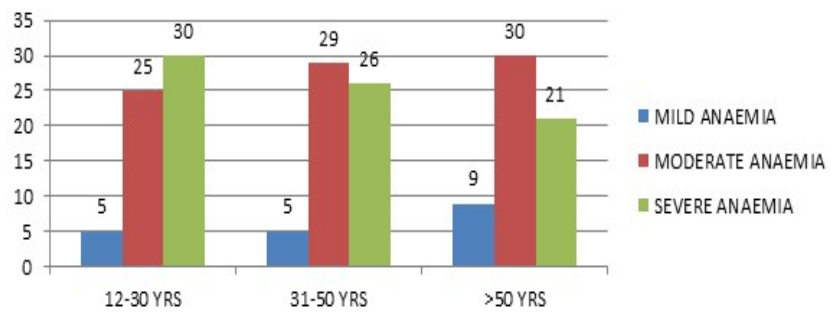

Figure 1: Incidence of anemia according to grade of severity

Figure .1 shows the bar diagram of severity grading of anaemia in the three age groups suggesting moderate grade as the most common among the three age groups. 
Table 2: Type of anaemia in study groups

\begin{tabular}{cccc}
\hline Type of anaemia & $\begin{array}{c}\text { Age group } \\
\text { 12-30 years }\end{array}$ & $\begin{array}{c}\text { Age group } \\
\text { 31-50 years }\end{array}$ & $\begin{array}{c}\text { Age group } \\
>50 \text { years }\end{array}$ \\
\hline Iron deficiency anaemia & 42 & 37 & 37 \\
Megaloblastic anaemia & 14 & 21 & 15 \\
Hemolytic anaemia & 02 & 00 & 00 \\
Anaemia of chronic disease & 02 & 02 & 08 \\
\hline
\end{tabular}

Table.2.shows the causes of anaemia in the three age groups which shows that the iron deficiency is the most common type of anaemia in all the three age groups.

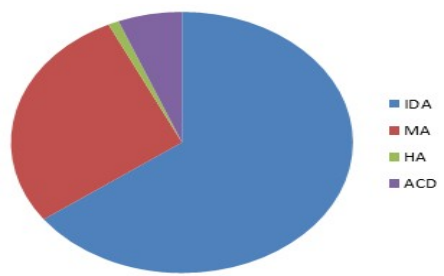

Figure 2: Causes of anaemia in females

Figure 2,shows the pie chart of causes of anaemia suggesting iron deficiency anaemia as the most common anaemia.

Table 3: Improvement in hematological indices in iron deficiency anaemia cases after supplementation of iron supplementations

\begin{tabular}{|c|c|c|c|c|c|c|c|c|c|}
\hline & \multicolumn{2}{|c|}{$\begin{array}{l}\text { Age group } \\
12-30 \text { years }\end{array}$} & \multirow[t]{2}{*}{$p$ value } & \multicolumn{2}{|c|}{$\begin{array}{l}\text { Age group } \\
31-50 \text { years }\end{array}$} & \multirow[t]{2}{*}{$p$ value } & \multicolumn{2}{|c|}{$\begin{array}{l}\text { Age group } \\
>50 \text { years }\end{array}$} & \multirow[t]{2}{*}{$\begin{array}{c}p \\
\text { value }\end{array}$} \\
\hline & $\begin{array}{c}\text { Before } \\
t / t\end{array}$ & $\begin{array}{c}\text { After } \\
t / t\end{array}$ & & $\begin{array}{c}\text { Before } \\
t / t\end{array}$ & $\begin{array}{c}\text { After } \\
t / t\end{array}$ & & $\begin{array}{c}\text { Before } \\
t / t\end{array}$ & $\begin{array}{c}\text { After } \\
t / t\end{array}$ & \\
\hline $\mathrm{Hb}$ & 8.22 & 10.23 & 0.000 & 8.588 & 11.058 & .000 & 8.93 & 11.45 & .000 \\
\hline HCT & 25.52 & 33.31 & 0.000 & 25.09 & 34.83 & .000 & 25.59 & 36.42 & .000 \\
\hline MCV & 68.50 & 77.66 & 0.000 & 67.95 & 77.67 & .000 & 68.38 & 79.60 & .000 \\
\hline $\mathrm{MCH}$ & 22.11 & 23.93 & 0.001 & 23.67 & 24.56 & .152 & 23.79 & 25.02 & .038 \\
\hline $\mathrm{MCHC}$ & 31.86 & 30.91 & 0.209 & 34.35 & 31.88 & .020 & 34.86 & 31.67 & .000 \\
\hline
\end{tabular}

Table.3.shows the improvement in hematological indices in iron deficiency anemia cases in different ages which shows that the hematological indices such as $\mathrm{Hb}, \mathrm{HCT}, \mathrm{MCV}$ has significant $\mathrm{p}$ values and henceforth prove that they improve with the iron supplentations.

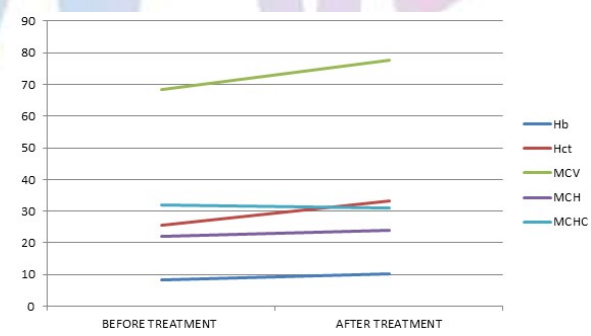

Figure 3: Improvement in hematological indices after supplementation of iron folic acid tablets

FIigure.3.line diagram shows the response to treatment with iron supplemtation suggesting that the maximum response upslope is present in Hemoglobin values.

Table 4: Improvement in hematological indices in megaloblastic anaemia cases after supplementation of vitamin B12 and folic acid

\begin{tabular}{|c|c|c|c|c|c|c|c|c|c|}
\hline & \multicolumn{2}{|c|}{$\begin{array}{l}\text { Age group } \\
12-30 \text { years }\end{array}$} & \multirow{2}{*}{$p$ value } & \multicolumn{2}{|c|}{$\begin{array}{l}\text { Age group } \\
31-50 \text { years }\end{array}$} & \multirow{2}{*}{$p$ value } & \multicolumn{2}{|c|}{$\begin{array}{l}\text { Age group } \\
>50 \text { years }\end{array}$} & \multirow{2}{*}{$\begin{array}{c}p \\
\text { value }\end{array}$} \\
\hline & $\begin{array}{c}\text { Before } \\
t / t\end{array}$ & $\begin{array}{c}\text { After } \\
t / t\end{array}$ & & $\begin{array}{c}\text { Before } \\
t / t\end{array}$ & $\begin{array}{c}\text { After } \\
t / t\end{array}$ & & $\begin{array}{c}\text { Before } \\
t / t\end{array}$ & $\begin{array}{c}\text { After } \\
t / t\end{array}$ & \\
\hline $\mathrm{Hb}$ & 7.44 & 9.700 & 0.000 & 7.45 & 10.06 & 0.000 & 8.15 & 10.30 & 0.000 \\
\hline $\mathrm{HCT}$ & 30.85 & 34.42 & 0.016 & 30.43 & 36.12 & 0.000 & 30.45 & 37.00 & 0.000 \\
\hline MCV & 107.07 & 87.43 & 0.000 & 107.19 & 85.81 & 0.000 & 105.45 & 89.09 & 0.003 \\
\hline $\mathrm{MCH}$ & 26.50 & 24.29 & 0.293 & 26.31 & 23.94 & 0.088 & 28.64 & 25.36 & 0.177 \\
\hline $\mathrm{MCHC}$ & 24.93 & 27.93 & 0.094 & 24.44 & 28.13 & 0.001 & 27.27 & 27.45 & 0.907 \\
\hline
\end{tabular}

Table.4.shows the improvement in hematological indices in megaloblastic anemia cases in different ages which shows that the hematological indices such as Hb, HCT, MCV has significant $\mathrm{p}$ values in age group (12-30years) and (31-50years) but only $\mathrm{Hb}$ and $\mathrm{HCT}$ improved in (age group $>50$ years)henceforth megaloblastic anaemia improve faster in younger age groups. 


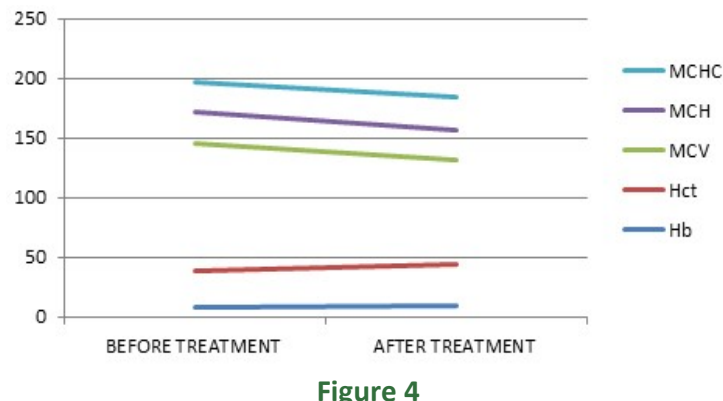

Figure.4. shows line diagram showing the response to treatment in females after receiving the vit B12 supplementation, suggesting the maximum improvement in hemoglobin with downsloping in MCV suggesting the normal erythropoiesis.

Table 5: Improvement in hematological indices in anaemia of chronic disease cases after treatment with erythropoetin

\begin{tabular}{cccc}
\hline & $\begin{array}{c}\text { Before } \\
\mathrm{t} / \mathrm{t}\end{array}$ & $\begin{array}{c}\text { After } \\
\mathrm{t} / \mathrm{t}\end{array}$ & $\mathrm{p}$ value \\
\hline $\mathrm{Hb}$ & 7.67 & 9.84 & 0.000 \\
$\mathrm{HCT}$ & 24.86 & 35.14 & 0.000 \\
$\mathrm{MCV}$ & 68.14 & 82.86 & 0.001 \\
$\mathrm{MCH}$ & 21.14 & 23.29 & 0.182 \\
$\mathrm{MCHC}$ & 30.86 & 28.14 & 0.223 \\
\hline
\end{tabular}

In our study the 8 females of chronic kidney disease are taken for study for anaemia of chronic kidney disease and were being treated with inj.erythropoeitin. Table 5.shows There is significant $\mathrm{p}$ value for hematological index $\mathrm{Hb}$ and $\mathrm{HCT}$ and hence suggestive of significant improvement.

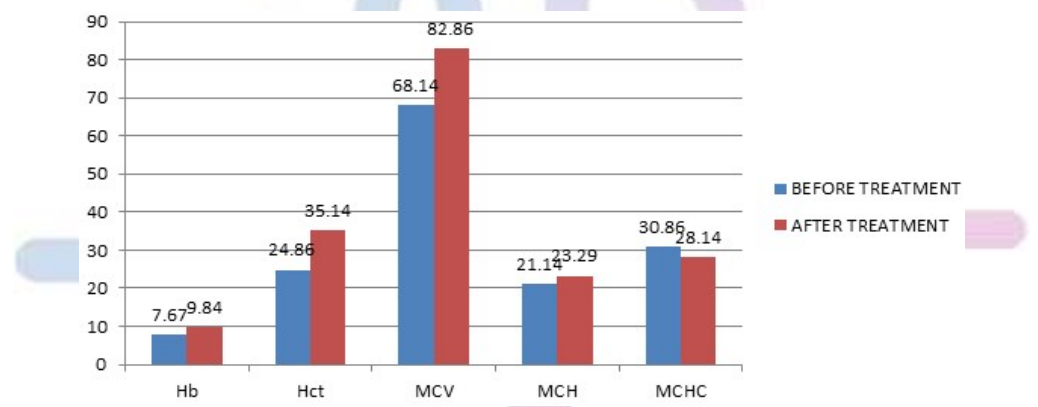

Figure 5: Improvement in hematological indices after treatment with erythropoetin

Figure.5. shows the comparison between the pre and post values of hematological indices in females with anaemia of chronic disease suggesting that there is drastic improvement in $\mathrm{Hb}, \mathrm{Hct}, \mathrm{MCV}, \mathrm{MCH}$ on receiving the erythropoietin supplements.

\section{DISCUSSION}

In our study iron deficiency anaemia is the most common type of anaemia. Tesfaye et $a .^{4}$ studied that the requirement for iron in fact doubles during adolescence as compared to younger age. There is a significant increase in the requirement of iron from preadolescent level of approximately $0.7-0.9 \mathrm{mg}$ iron per day to as much as 1.37 $1.88 \mathrm{mg}$ per day in adolescent boys and 1.40-3.27 in adolescent girls. This is the reason for higher prevalence of iron deficiency anaemia in females of age group (1230 years).After treatment, it was observed that the $p$ value is significant as we compare the pre and post treatment red cell indices. There is significant improvement of red cell indices after receiving the treatment for the period of 3 months. In our study, the highest incidence of megaloblastic anaemia was observed in the age group(3150years).In our study the results shows the improvement of hematological indices after receiving B12 supplementations in the form of containing cyanocobalamin 5 microgram, ferrous fumarate $100 \mathrm{mg}$ and folic acid $0.5 \mathrm{mg}$ per $5 \mathrm{ml}$ of the syrup taking $5 \mathrm{ml}$ BID for three months shows the significant $p$ values in the value of $\mathrm{Hb}, \mathrm{MCV}, \mathrm{MCH}, \mathrm{MCHC}$. In this case with treatment the $\mathrm{MCV}$ values decreases shifting megaloblastic erythropoisis to the normoblastic erythropoisis. The maximum incidence of hemolytic anaemia was observed in the age group (12-30years) and the two cases is of thalassemia intermediate. The hemoglobin electrophoresis result shows elevated level of $\mathrm{HbA} 2$ and $\mathrm{HbF}$. The study done by Galanello et al. shows that the total annual 
incidence of symptomatic individuals is estimated at 1 in 100,000 throughout the world. ${ }^{7}$ Our study also shows only two cases of beta thalassemia as anaemia in young females. The maximum cases anaemia due to chronic disease were noted in the age group ( $>50$ years), hence it's the important cause of anaemia in the elderly patients. McClellan et $a l .{ }^{8}$ study shows that patients with diabetes or CKD reported a higher prevalence of anaemia of $10-20 \%$. In our study, 5 out 8 patients of anaemia due to chronic disease having chronic kidney disease were anemic, that constitute that $62.5 \%$ females suffering from chronic kidney disease were anemic. The dose of iron sucrose $10 \mathrm{~mL}(200 \mathrm{mg}$ elemental iron) diluted in a maximum of $100 \mathrm{~mL}$ of $0.9 \%$ sodium chloride IV over at least 15 minutes and the erythropoietin is50-100 units/kg IV 3 times weekly. They showed improvement of blood cell indices after receiving the inj.erythropoietin. There is significant $p$ value in the pre and post treatment comparison of red cell indices suggesting the drastic improvement of the red cell indices after receiving the inj.erythropoietin. In the pretreatment chart, there was significant $p$ value between age group 1 and 3 that is between (12-30years) and (>50years) for the hemoglobin values. A very significant $p$ value is found in $\mathrm{MCHC}$ value between the age group (12-30years) and ( $>50$ years).In the post treatment chart, there is significant $p$ value between the age group (12-30years) and (3150 years) for $\mathrm{Hb}$ which was not present in the pre-treatment chart showing significant change in the values for $\mathrm{Hb}$. The $\mathrm{p}$ value is significant in comparison between age group(1230 years) and ( $>50$ years). The $p$ value is significant in hematocrit and RBC count suggesting drastic improvement in the RBC count in response to treatment.

\section{CONCLUSION}

In the present study the incidence according to grades of severity is maximum for moderate grade of anaemia having the highest number of cases in the lower start a of the society. This suggest that poverty causing lack of balanced diet, illiteracy, lack of awareness as the important factors leading to the development of anaemia Elderly females are also susceptible to the development of anaemia, the main cause is the underlying chronic diseases. In our study it is found that chronic kidney disease(CKD) (increase level of creatinine level with small sized kidneys) as the major cause of anaemia of chronic disease in elderly and these females are treated with erythropoietin and this improve their blood cell indices decrease the need of

\section{Policy for Articles with Open Access:}

Authors who publish with MedPulse International Journal of Medicine, Print ISSN: 2550-7583, Online ISSN: 2636-4751 agree to the following terms: Authors retain copyright and grant the journal right of first publication with the work simultaneously licensed under a Creative Commons Attribution License that allows others to share the work with an acknowledgement of the work's authorship and initial publication in this journal. Authors are permitted and encouraged to post links to their work online (e.g., in institutional repositories or on their website) prior to and during the submission process, as it can lead to productive exchanges, as well as earlier and greater citation of published work. dialysis. The present need of the health care system is to develop the awareness among the females about importance of balanced diet, regular check up, menstrual hygiene. The oral supplements have good response to treatment and the compliance for the patient is better than injectables. Food fortification with important micronutrients can have the better impact on the nutritional status. There should be awareness regarding the ill effects of consignees marriages of the parents can lead to hemoglobinopathies among their offspring making them blood transfusion dependant. Elderly females especially post menopausal due to hormonal disturbances and secondary chronic diseases are more susceptible to the development of anaemia. The periodic checkups and the healthy lifestyle can help to fight with these problems.

Hence it's the need of an hour to implement the early diagnostic tool of anaemia at various community centers including schools and colleges and to create awareness

\section{REFERENCES}

1. Rammohan A, Awofeso N,Robitaille M-C. Addressing Female Iron-Deficiency Anaemia in India: Is Vegetarianism the Major Obstacle?International Scholarly Research NoticesPublic Health 2012;Article ID 765476:1-8.

2. Ciesla B. Hematology in Practice. 2nd ed. Philadelphia, PA: FA Davis Company; 2011.

3. Chow S, Shao J, Wang H. 2008. Sample Size Calculations in Clinical Research. 2nd Ed. Chapman and Hall/CRC Biostatistics Series. page 89.

4. Tesfaye M, Yemane T, Adisu W, Asres Y, Gedefaw L. Anaemia and iron deficiency among school adolescents: burden, severity, and determinant factors in southwest

5. Institute of Medicine (US) Committee on Micronutrient Deficiencies; Howson CP, Kennedy ET, Horwitz A, editors. Prevention of Micronutrient Deficiencies: Tools for Policymakers and Public Health Workers. Washington (DC): National Academies Press (US); 1998. 3, Prevention of Iron Deficiency. Available https://www.ncbi.nlm.nih.gov/books/NBK230103/

6. Zavaleta N, Respicio G, Garcia T. Efficacy and Acceptability of Two Iron Supplementation Schedules in Adolescent School Girls in Lima, Peru. The Journal of Nutrition 2000;130:462S464S.

7. Galanello Renzo, OrigaRaffaella. Beta-thalassemia. OrphanetJRare Dis 2010;2010(5):11.

8. McClellan W, Aronoff SL, Bolton WK, Hood S, Lorber DL, Tang KL, et al.. The prevalence of anaemia in patients with chronic kidney disease. Curr Med Res Opin. 2004;20(9):150110 .

\section{Source of Support: None Declared} Conflict of Interest: None Declared Ethiopia. Adolesc Health Med Ther. 2015;6:189-96. 